\title{
Deoxyribonucleic Acid-Deoxyribonucleic Acid Hybridization Analysis of Actinobacillus actinomycetemcomitans and Haemophilus aphrophilus
}

\author{
THOMAS V. POTTS ${ }^{1.2 *}$ AND ELAINE M. BERRY ${ }^{1}$ \\ Department of Oral Biology ${ }^{1}$ and Department of Operative Denistry, ${ }^{2}$ State University of New York at \\ Buffalo, Buffalo, New York 14214
}

\begin{abstract}
Deoxyribonucleic acids (DNAs) were isolated and purified from 20 strains of Actinobacillus actinomycetemcomitans, 6 strains of Haemophilus aphrophilus, 2 strains of Haemophilus paraphrophilus, 2 strains of Haemophilus pleuropneumoniae, 2 strains of Haemophilus paraphrohaemolyticus, 2 strains of Haemophilus influenzae, and 1 strain each of Actinobacillus lignieresii, Actinobacillus suis, Haemophilus aegyptius, Haemophilus parainfluenzae, and Haemophilus parahaemolyticus. The guanine-plus-cytosine contents of the DNAs were determined, and they agreed closely with previous estimates. DNA-DNA hybridization analyses revealed that all of the strains identified as A. actinomycetemcomitans were at least $69 \%$ homologous to DNA probes from two A. actinomycetemcomitans strains (strains NCTC $9710^{\mathrm{T}}[\mathrm{T}=$ type strain] and Y4). The $H$. aphrophilus and $H$. paraphrophilus strains were homologous to the two $A$. actinomycetemcomitans probes at levels of 25 to $37 \%$. The DNAs of all A. actinomycetemcomitans strains were homologous to a DNA probe from $H$. aphrophilus strain NCTC 5906 at levels of 30 to $39 \%$. The two strains of $H$. paraphrophilus tested were homologous to the $H$. aphrophilus probe at levels of 73 and $77 \%$, indicating a very close relationship between these groups of organisms. H. parainfluenzae strain ATCC 9796 DNA seemed to be homologous to the $H$. aphrophilus and $A$. actinomycetemcomitans probes at low but significant levels (12 to 16\%). All of the other strains of haemophili and actinobacilli tested gave $10 \%$ or less homology with the three test probes.
\end{abstract}

Actinobacillus actinomycetemcomitans, Haemophilus aphrophilus, and Haemophilus paraphrophilus are frequently cultured from oral cavities and make up a small but significant component of human dental plaques $(15,16,18$, $19,27,31$ ). These organisms have been isolated from a variety of nonoral infections and are pathogens of some interest $(6,12,17,18,30,33)$. A. actinomycetemcomitans has been isolated from destructive periodontal lesions $(27,31)$ and has been shown to cause alveolar bone loss when it is implanted in gnotobiotic rats (8). These observations indicate that the characterization and classification of these organisms are of clinical importance.

The phenotypic similarity between $H$. aphrophilus and A. actinomycetemcomitans was first noted by King and Tatum (17), who suggested that the placement of these organisms in separate genera was "most unsatisfactory." Subsequent investigations have also indicated a close phenotypic relationship between these two species $(16,26)$. On the other hand, an investigation
(24) in which optical deoxyribonucleic acid (DNA) reassociation methods were used (5) suggested that $A$. actinomycetemcomitans is more closely related to Actinobacillus lignieresii than to $H$. aphrophilus. Soluble protein profiles have also shown distinctly different patterns for A. actinomycetemcomitans, $H$. aphrophilus, and other Actinobacillus species (2).

The nature of the relationships which $A$. actinomycetemcomitans and $H$. aphrophilus have with other species of Haemophilus, such as $H$. paraphrophilus and Haemophilus parainfluen$z a e$, has not been completely delineated. However, a close relationship has been demonstrated between $H$. aphrophilus and $H$. paraphrophilus strains $(13,24,29)$.

This investigation was undertaken to determine the genetic variation in oral isolates of $A$. actinomycetemcomitans and to assess the relationship between $A$. actinomycetemcomitans and representative strains of several species of haemophili and actinobacilli. The relationships of $H$. aphrophilus to Haemophilus paraphrohae- 
molyticus (34) and to other species of haemophili and actinobacilli were also assessed.

\section{MATERIALS AND METHODS}

Strains and media. All of the strains used in this study, as well as their sources and sites of origin, are listed in Table 1 . The criteria used to identify the $A$. actinomycetemcomitans isolates, as well as their phenotypic properties, have been described previously (26). The two strains listed as $H$. pleuropneumoniae strains (ATCC 27089 and ATCC 27090) were previously designated Haemophilus parahaemolyticus (14).

Liquid culture of all actinobacilli was accomplished in a medium containing $37 \mathrm{~g}$ of brain heart infusion broth per liter, $5 \mathrm{~g}$ of yeast extract per liter, and $1.0 \mathrm{~g}$ of $\mathrm{NaHCO}_{3}$ per liter. All haemophili were grown in liquid medium containing $18.5 \mathrm{~g}$ of brain heart infusion broth per liter, $10 \mathrm{~g}$ of yeast extract per liter, $10 \mathrm{~g}$ of tryptose per liter, $10 \mathrm{~g}$ of Biosate peptone (Becton Dickinson \& Co., Cockeysville, Md.) per liter, $1.0 \mathrm{mg}$ of vitamin $\mathrm{K}_{1}$ per liter, $1.0 \mathrm{mg}$ of hemin per liter, $1.6 \mathrm{~g}$ of $\mathrm{NaHCO}_{3}$ per liter, and $10 \mathrm{ml}$ of Isovitale X (Becton, Dickinson \& Co.) per liter.

The bacterial cells used for DNA purification were grown in 1.5-liter quantities of the appropriate media. The cells were harvested by centrifugation during the late $\log$ phase of growth, washed with $\mathrm{NaCl}$-ethylenediaminetetraacetate buffer $(0.15 \mathrm{M} \mathrm{NaCl}, 0.01 \mathrm{M}$ ethylenediaminetetraacetate, $\mathrm{pH} 8.0$ ), and stored at $-20^{\circ} \mathrm{C}$ until use.

Cell lysis. Cells were washed and centrifuged twice with $100 \mathrm{ml}$ of $\mathrm{NaCl}$-ethylenediaminetetraacetate buff$\mathrm{er}$ and then resuspended in $40 \mathrm{ml}$ of $\mathrm{NaCl}$-ethylenediaminetetraacetate buffer. Sodium dodecyl sulfate was

TABLE 1. List of strains used

\begin{tabular}{|c|c|c|c|}
\hline Species & Strain & Source $^{a}$ & Site of isolation \\
\hline \multirow[t]{20}{*}{ A. actinomycetemcomitans } & 1 & Slots & Tongue \\
\hline & 32 & Slots & Tongue \\
\hline & 58 & Slots & Cheek mucosa \\
\hline & 67 & Slots & Cheek mucosa \\
\hline & 68 & Slots & Dental plaque \\
\hline & 69 & Slots & Dental plaque \\
\hline & 74 & Slots & Dental plaque \\
\hline & 75 & Slots & Dental plaque \\
\hline & 78 & Slots & Cheek mucosa \\
\hline & 83 & Slots & Cheek mucosa \\
\hline & 88 & Slots & Cheek mucosa \\
\hline & 105 & Slots & Dental plaque \\
\hline & 120 & Slots & Dental plaque \\
\hline & 131 & Slots & Dental plaque \\
\hline & NCTC 9709 & NCTC & Lumbar abscess \\
\hline & NCTC $9710^{\mathrm{T}}$ & NCTC & Lung abscess \\
\hline & АТCC 29522 & ATCC & Mandibular abscess \\
\hline & ATCC 29523 & ATCC & Blood \\
\hline & ATCC 29524 & ATCC & Chest aspirate \\
\hline & Y4 & FDC & Dental plaque \\
\hline A. lignieresii & ATCC 19393 & ATCC & Bovine lesion \\
\hline A. suis & ATCC 15557 & ATCC & Blood, adult swine \\
\hline H. aegyptius & ATCC 11116 & ATCC & Conjunctiva \\
\hline \multirow[t]{5}{*}{ H. aphrophilus } & NCTC $5906^{b}$ & NCTC & Endocarditis \\
\hline & NCTC $5907^{b}$ & NCTC & Endocarditis \\
\hline & NCTC $5908^{b}$ & NCTC & Endocarditis \\
\hline & ATCC 13252 & ATCC & Unknown \\
\hline & ATCC $19415^{\mathrm{T} b}$ & ATCC & Endocarditis \\
\hline \multirow[t]{2}{*}{ H. influenzae } & ATCC 9007 & ATCC & Unknown \\
\hline & ATCC 9332 & ATCC & Unknown \\
\hline H. parahaemolyticus & $\operatorname{ATCC} 10014^{\mathrm{T}}$ & ATCC & Pulmonary infection \\
\hline \multirow[t]{2}{*}{ H. pleuropneumoniae } & ATCC 27089 & ATCC & Swine pleuropneumonia \\
\hline & ATCC 27090 & ATCC & Swine abscess \\
\hline H. parainfluenzae & ATCC 9796 & ATCC & Unknown \\
\hline \multirow{3}{*}{ H. paraphrohaemolyticus } & $\operatorname{ATCC} 29237^{\mathrm{T}}$ & ATCC & Sputum \\
\hline & ATCC 29238 & ATCC & Sputum \\
\hline & ATCC 29239 & ATCC & Throat swab \\
\hline \multirow{2}{*}{ H. paraphrophilus } & ATCC 29240 & ATCC & Parietal abscess \\
\hline & ATCC 29242 & ATCC & Trachea \\
\hline
\end{tabular}

\footnotetext{
a ATCC, American Type Culture Collection, Rockville, Md.; NCTC, National Collection of Type Cultures,
} Central Public Health Laboratory, London, England; FDC, Forsyth Dental Center, Boston, Mass.; Slots, J. Slots, State University of New York at Buffalo Dental School, Buffalo, N.Y.

${ }^{b}$ Strains isolated from the blood of one patient by Khairat (12). 
added to a final concentration of $2 \%$, and lysis was observed as a clearing of the mixture. Rapid lysis was apparent at room temperature with all strains of actinobacilli and haemophili used in this study.

DNA purification, $\mathbf{G}+\mathrm{C}$ content determination, and DNA-DNA hybridization technique. DNA was purified as previously described (25) by using a modification of the technique of Marmur (21). The guanine-plus-cytosine $(\mathrm{G}+\mathrm{C})$ content of each DNA was determined by the thermal melting point method $(23,25)$. In our DNA-DNA hybridization procedure we used the S1 nuclease assay for detecting hybrid complexes (4), as described previously (25). The hybridization reactions were performed at $63^{\circ} \mathrm{C}$; this temperature is $25^{\circ} \mathrm{C}$ below the melting temperature of the probe DNAs, as previously recommended $(10,22)$.

\section{RESULTS}

The melting temperature and $\mathrm{G}+\mathrm{C}$ content of the DNA of each strain used in this study are shown in Table 2; the species are arranged in order of decreasing melting temperature and $\mathrm{G}+\mathrm{C}$ content. Strains identified as A. actinomycetemcomitans contained DNAs with $\mathrm{G}+\mathrm{C}$ contents in the range from 44.9 to $46.6 \mathrm{~mol} \%$. This range is distinct from and does not overlap the $\mathrm{G}+\mathrm{C}$ contents of the DNAs of the strains of $H$. aphrophilus and $H$. paraphrophilus which we examined. $H$. aphrophilus and $H$. paraphrophilus DNAs melted in the same temperature range and had $\mathrm{G}+\mathrm{C}$ contents between 43.2 and 44.4 mol\%. The other strains of haemophili and actinobacilli tested all had $\mathrm{G}+\mathrm{C}$ contents of $42 \mathrm{~mol} \%$ or less.

Table 3 shows the results of DNA-DNA hybridizations in which we used two tritiated $A$. actinomycetemcomitans probes $\left({ }^{3} \mathrm{H}\right.$ labeled strain NCTC $9710^{\mathrm{T}}$ and $\mathrm{Y} 4$ DNAs $[\mathrm{T}=$ type strain]) and one tritiated $H$. aphrophilus probe

TABLE 2. $\mathrm{G}+\mathrm{C}$ contents of bacterial DNAs

\begin{tabular}{|c|c|c|c|c|}
\hline Species & Strain & $\begin{array}{c}\text { No. of } \\
\text { measurements }\end{array}$ & $\begin{array}{l}\text { Mean melting } \\
\text { temp }\left({ }^{\circ} \mathrm{C}\right)\end{array}$ & $\begin{array}{c}\mathrm{G}+\mathrm{C} \text { content } \\
\quad(\mathrm{mol} \%)\end{array}$ \\
\hline \multirow{20}{*}{ A. actinomycetemcomitans } & 1 & 2 & 88.2 & 46.1 \\
\hline & 32 & 2 & 87.9 & 45.4 \\
\hline & 58 & 2 & 88.1 & 45.9 \\
\hline & 67 & 2 & 88.1 & 45.9 \\
\hline & 68 & 2 & 87.9 & 45.4 \\
\hline & 69 & 3 & 87.9 & 45.4 \\
\hline & 74 & 3 & 87.9 & 45.4 \\
\hline & 75 & 3 & 88.3 & 46.3 \\
\hline & 78 & 2 & 88.4 & 46.6 \\
\hline & 83 & 2 & 87.4 & 45.4 \\
\hline & 88 & 2 & 88.1 & 45.9 \\
\hline & 105 & 3 & 88.1 & 45.9 \\
\hline & 120 & 2 & 87.7 & 44.9 \\
\hline & 131 & 2 & 88.0 & 45.6 \\
\hline & NCTC 9709 & 2 & 88.0 & 45.6 \\
\hline & NCTC $9710^{T}$ & 3 & 88.0 & 45.6 \\
\hline & ATCC 29522 & 7 & 88.1 & 45.9 \\
\hline & ATCC 29523 & 3 & 87.7 & 44.9 \\
\hline & ATCC 29524 & 5 & 88.0 & 45.6 \\
\hline & Y4 & 3 & 88.3 & 46.3 \\
\hline \multirow[t]{5}{*}{ H. aphrophilus } & NCTC 5906 & 4 & 87.1 & 43.4 \\
\hline & NCTC 5907 & 2 & 87.0 & 43.2 \\
\hline & NCTC 5908 & 3 & 87.1 & 43.4 \\
\hline & ATCC 13252 & 2 & 87.0 & 43.2 \\
\hline & ATCC $19415^{\mathrm{T}}$ & 3 & 87.2 & 43.7 \\
\hline \multirow[t]{2}{*}{ H. paraphrophilus } & ATCC 29240 & 3 & 87.5 & 44.4 \\
\hline & ATCC 29242 & 3 & 87.0 & 43.2 \\
\hline A. lignieresii & ATCC 19393 & 3 & 86.5 & 42.0 \\
\hline A. suis & ATCC 15557 & 4 & 86.2 & 41.2 \\
\hline H. parainfluenzae & АТСС 9796 & 3 & 86.0 & 40.7 \\
\hline \multirow{2}{*}{$\begin{array}{l}\text { H. influenzae } \\
\text { H. }\end{array}$} & ATCC 9007 & 3 & 85.8 & 40.2 \\
\hline & ATCC 9332 & 3 & 85.4 & 39.3 \\
\hline \multirow[t]{3}{*}{ H. paraphrohaemolyticus } & ATCC $29237^{\mathrm{T}}$ & 3 & 85.7 & 39.9 \\
\hline & ATCC 29238 & 3 & 85.9 & 40.5 \\
\hline & ATCC 29239 & 3 & 85.8 & 40.2 \\
\hline H. aegyptius & ATCC 11116 & 3 & 85.2 & 38.8 \\
\hline H. parahaemolyticus & ATCC $10014^{\mathrm{T}}$ & 3 & 85.0 & 38.2 \\
\hline \multirow[t]{2}{*}{ H. pleuropneumoniae } & ATCC 27089 & 5 & 86.4 & 41.7 \\
\hline & ATCC 27090 & 3 & 85.2 & 38.8 \\
\hline
\end{tabular}


TABLE 3. Results of DNA-DNA hybridizations

\begin{tabular}{|c|c|c|c|c|c|c|c|}
\hline \multicolumn{2}{|c|}{ Source of unlabeled DNA } & \multicolumn{2}{|c|}{$\begin{array}{c}{ }^{3} \mathrm{H} \text {-labeled strain NCTC } 9710^{\mathrm{T}} \\
\text { DNA }\end{array}$} & \multicolumn{2}{|c|}{${ }^{3} \mathrm{H}$-labeled strain Y4 DNA } & \multicolumn{2}{|c|}{$\begin{array}{c}{ }^{3} \mathrm{H} \text {-labeled strain NCTC } 5906 \\
\text { DNA }\end{array}$} \\
\hline Species & Strain & $\begin{array}{c}\text { No. of } \\
\text { measure- } \\
\text { ments }\end{array}$ & $\begin{array}{l}\% \text { Hybridi- } \\
\text { zation }\end{array}$ & $\begin{array}{l}\text { No. of } \\
\text { measure- } \\
\text { ments }\end{array}$ & $\begin{array}{c}\% \\
\text { Hybridi- } \\
\text { zation }\end{array}$ & $\begin{array}{l}\text { No. of } \\
\text { measure- } \\
\text { ments }\end{array}$ & $\begin{array}{c}\% \\
\text { Hybridi- } \\
\text { zation }\end{array}$ \\
\hline \multirow{19}{*}{$\begin{array}{l}\text { A. actinomycetem- } \\
\text { comitans }\end{array}$} & 1 & 2 & $90 \pm 5^{a}$ & 1 & 99 & 2 & $31 \pm 3$ \\
\hline & 32 & 2 & $84 \pm 6$ & 1 & 85 & 2 & $31 \pm 3$ \\
\hline & 58 & 2 & $78 \pm 2$ & 1 & 91 & 2 & $34 \pm 1$ \\
\hline & 67 & 2 & $86 \pm 7$ & 2 & $100 \pm 7$ & 1 & 32 \\
\hline & 68 & 2 & $89 \pm 11$ & 1 & 85 & 1 & 30 \\
\hline & 69 & 2 & $96 \pm 2$ & 2 & $93 \pm 5$ & 2 & $32 \pm 3$ \\
\hline & 74 & 3 & $72 \pm 10$ & 4 & $70 \pm 4$ & 3 & $39 \pm 8$ \\
\hline & 75 & 4 & $80 \pm 7$ & 5 & $86 \pm 4$ & 5 & $36 \pm 4$ \\
\hline & 78 & 2 & $78 \pm 4$ & 2 & $77 \pm 7$ & 2 & $32 \pm 1$ \\
\hline & 88 & 2 & $77 \pm 5$ & 2 & $90 \pm 5$ & 2 & $33 \pm 8$ \\
\hline & 105 & 2 & $69 \pm 3$ & 2 & $85 \pm 6$ & 2 & $31 \pm 3$ \\
\hline & 120 & 2 & $97 \pm 5$ & 2 & $90 \pm 4$ & 2 & $33 \pm 3$ \\
\hline & 131 & 2 & $74 \pm 6$ & 1 & 81 & 2 & $31 \pm 3$ \\
\hline & NCTC 9709 & 2 & $86 \pm 8$ & 2 & $87 \pm 2$ & 2 & $31 \pm 2$ \\
\hline & NCTC $9710^{\mathrm{T}}$ & & 100 & 6 & $88 \pm 7$ & 5 & $35 \pm 8$ \\
\hline & ATCC 29522 & 6 & $90 \pm 10$ & 3 & $80 \pm 1$ & 3 & $30 \pm 3$ \\
\hline & ATCC 29523 & 8 & $81 \pm 3$ & 5 & $86 \pm 3$ & 6 & $31 \pm 3$ \\
\hline & ATCC 29524 & 8 & $87 \pm 8$ & 8 & $98 \pm 5$ & 9 & $32 \pm 4$ \\
\hline & Y4 & 7 & $83 \pm 10$ & & 100 & 6 & $32 \pm 2$ \\
\hline \multirow[t]{5}{*}{ H. aphrophilus } & NCTC 5906 & 3 & $35 \pm 3$ & 2 & $34 \pm 1$ & & 100 \\
\hline & NCTC 5907 & 2 & $32 \pm 5$ & 2 & $30 \pm 1$ & 2 & $96 \pm 8$ \\
\hline & NCTC 5908 & 2 & $35 \pm 5$ & 2 & $31 \pm 3$ & 2 & $90 \pm 9$ \\
\hline & ATCC 13252 & 2 & $31 \pm 4$ & 2 & $32 \pm 3$ & 2 & $92 \pm 7$ \\
\hline & ATCC $19415^{\mathrm{T}}$ & 2 & $32 \pm 3$ & 1 & 25 & 2 & $98 \pm 8$ \\
\hline \multirow[t]{2}{*}{ H. paraphrophilus } & ATCC 29240 & 3 & $32 \pm 7$ & 4 & $33 \pm 3$ & 2 & $73 \pm 1$ \\
\hline & ATCC 29242 & 3 & $37 \pm 1$ & 4 & $36 \pm 3$ & 3 & $77 \pm 4$ \\
\hline A. lignieresii & ATCC 19393 & 4 & $7 \pm 5$ & 3 & $9 \pm 2$ & 5 & $7 \pm 1$ \\
\hline A. suis & ATCC 15557 & 2 & $5 \pm 4$ & 2 & $3 \pm 1$ & 1 & 5 \\
\hline H. parainfluenzae & ATCC 9796 & 3 & $16 \pm 4$ & 2 & $12 \pm 2$ & 2 & $15 \pm 1$ \\
\hline \multirow[t]{2}{*}{ H. influenzae } & ATCC 9007 & 2 & $9 \pm 3$ & 2 & $7 \pm 4$ & 2 & $6 \pm 0$ \\
\hline & ATCC 9332 & 3 & $6 \pm 2$ & 2 & $9 \pm 1$ & 2 & $6 \pm 2$ \\
\hline H. paraphro- & ATCC $29237^{\mathrm{T}}$ & 2 & $2 \pm 5$ & 1 & 4 & 2 & $6 \pm 1$ \\
\hline haemolyticus & ATCC 29238 & 1 & 9 & 2 & $3 \pm 3$ & 1 & 9 \\
\hline H. aegyptius & ATCC 11116 & 3 & $8 \pm 2$ & 2 & $10 \pm 1$ & 2 & $2 \pm 2$ \\
\hline H. parahaemolyticus & ATCC $10014^{\mathrm{T}}$ & 2 & $7 \pm 3$ & 2 & $0 \pm 0$ & 3 & $0 \pm 0$ \\
\hline \multirow[t]{2}{*}{ H. pleuropneumoniae } & ATCC 27089 & 1 & 7 & 2 & $6 \pm 2$ & 1 & $4 \pm 3$ \\
\hline & ATCC 27090 & 2 & $6 \pm 6$ & 2 & $6 \pm 2$ & 2 & $9 \pm 2$ \\
\hline Escherichia coli & B & 2 & $3 \pm 1$ & 2 & $3 \pm 0$ & 2 & $2 \pm 2$ \\
\hline
\end{tabular}

${ }^{a}$ Mean \pm standard deviation. 
$\left({ }^{3} \mathrm{H}\right.$-labeled strain NCTC 5906 DNA). Table 3 also shows the number of hybridizations performed with each pair of DNAs and lists the means and standard deviations for these observations. All $A$. actinomycetemcomitans strains hybridized with the ${ }^{3} \mathrm{H}$ labeled strain NCTC $9710^{\mathrm{T}}$ and $\mathrm{Y} 4$ probes at levels of $69 \%$ or higher, and all $H$. aphrophilus and $H$. paraphrophilus strains hybridized with these probes at levels of 25 to $37 \%$. Strains of all of the other species examined except $H$. parainfluenzae hybridized with these $A$. actinomycetemcomitans probes at levels of $10 \%$ or less. $H$. parainfluenzae strain ATCC 9796 hybridized with the two A. actinomycetemcomitans probes at levels of 12 to $16 \%$.

The tritiated $H$. aphrophilus probe $\left({ }^{3} \mathrm{H}-\mathrm{la}-\right.$ beled strain NCTC 5906 DNA) hybridized with unlabeled DNA from A. actinomycetemcomitans strains at levels of 30 to $39 \%$. These results are similar to those seen when the recipricol experiment was performed (tritiated A. actinomycetemcomitans probes were hybridized with unlabeled $H$. aphrophilus DNA). The $H$. aphrophilus probe gave high levels of homology (90 to 98\%) with the four other strains classified as $H$. aphrophilus, as well as with two reference strains classified as $H$. paraphrophilus (73 and 77\%). H. parainfluenzae strain ATCC 9796 was homologous at the $15 \%$ level to the $H$. aphrophilus probe, whereas all of the other strains tested gave levels of homology of $9 \%$ or less.

\section{DISCUSSION}

Our determinations of $\mathrm{G}+\mathrm{C}$ contents are in close agreement with previous estimates $(7,13$, 19). The only exception is A. ligniersii DNA, which we measured at $42 \mathrm{~mol} \% \mathrm{G}+\mathrm{C}$, whereas Mannheim et al. (20) obtained a value of 43.4 to $44.2 \mathrm{~mol} \% \mathrm{G}+\mathrm{C}$. The $\mathrm{G}+\mathrm{C}$ content of $H$. pleuropneumoniae strain ATCC 27089 appears to be significantly different than the $\mathrm{G}+\mathrm{C}$ content of strain ATCC 27090 . This result may indicate some heterogeneity in this group of organisms.

After using the filter-binding method of DNADNA hybridization, Johnson (9) suggested that homology values in the range from 20 to $60 \%$ indicate that organisms should be considered separate species within the same genus, whereas levels of homology greater than $60 \%$ indicate that organisms should be placed within the same species. According to this scheme, subspecies designations are appropriate for organisms with 60 to $70 \%$ levels of homology. With these guidelines in mind and with the observation that the S1 nuclease assay gives levels of homology that are equal to or slightly below those given by the filter-binding method $(3,11)$, we made the following interpretations with regard to our DNADNA hybridization data.
Our DNA-DNA hybridization results clearly indicated that the organisms isolated as A. actinomycetemcomitans were highly interrelated and should be considered one species. The two $A$. actinomycetemcomitans probes used were from organisms in different serogroups (28); however, the data obtained with these probes did not identify distinct subgroups within this species. Our data do suggest that the commonly used laboratory strains Y4 and ATCC 29524 are very closely related. It is also evident that $A$. actinomycetemcomitans is more closely related to $H$. aphrophilus and $H$. paraphrophilus (25 to $39 \%$ homology) than to either A. lignieresii or Actinobacillus suis. Also, a low but seemingly significant level of homology was observed between A. actinomycetemcomitans and $H$. parainfluenzae strain ATCC 9796 (12 to 16\%). These observations move us to suggest that either $A$. actinomycetemcomitans should be placed in the genus Haemophilus or a new genus should be created that would include $A$. actinomycetemcomitans, $H$. aphrophilus, and $H$. paraphrophilus species. Placement of A. actinomycetemcomitans in the genus Haemophilus would require an alteration in the definition of this genus to include organisms which do not require either $\mathrm{X}$ or $\mathrm{V}$ factors, an idea which has met with considerable resistance in the past $(1,32)$.

These results are at variance with those of a previous study (24), in which it was reported that $A$. actinomycetemcomitans is related at the 20 to $40 \%$ level to all other species of haemophili and actinobacilli tested (all of the species which we used in this study were included). A. actinomycetemcomitans was also found to be more closely related to $A$. suis and $A$. lignieresii than to $H$. aphrophilus and $H$. paraphrophilus. We believe that these discrepancies are most likely accounted for by the different methodologies employed. Pohl (24) used optical measurements of DNA-DNA renaturation rates (5). This method employs much shorter hybridization times (30 to $40 \mathrm{~min}$ ). In addition, the two DNAs tested are present in solution at the same relatively high concentration ( 75 to $80 \mu \mathrm{g} / \mathrm{ml}$ ). It seems possible that a less specific form of hybrid formation is being measured or that the contributions of self-hybridization to the renaturation may be difficult to assess or both. Further study on these points is needed.

The data obtained by using a tritiated $H$. aphrophilus probe $\left({ }^{3} \mathrm{H}\right.$-labeled strain NCTC 5906 DNA) were similar to those obtained in the reciprocal experiment which used the two tritiated A. actinomycetemcomitans probes and reinforced the view that $H$. aphrophilus and $A$. actinomycetemcomitans should be placed in the same genus. The results obtained with the $H$. aphrophilus probe also indicated that $H$. aphro- 
philus and the two strains of $H$. paraphrophilus examined are very closely related (73 and $77 \%$ homology). Perhaps a subspecies designation would be more appropriate for $H$. paraphrophilus. However, an alteration in nomenclature should await a more exhaustive hybridization analysis of a series of $H$. aphrophilus and $H$. paraphrophilus isolates in order to determine whether the two groups are genetically distinguishable. $H$. parainfluenzae strain ATCC 9796 seems measurably related to $H$. aphrophilus (15\% homology), whereas all other species of haemophili and actinobacilli tested gave homology levels of $9 \%$ or less with the $H$. aphrophilus probe, indicating a very distant relationship between $H$. aphrophilus and these organisms.

We have been unable to demonstrate a relationship between $H$. aphrophilus and $H$. paraphrohaemolyticus strains ATCC $29237^{\mathrm{T}}$ and ATCC 29238, as previously described (24). These results reinforce the view previously expressed by Kilian (13) that $H$. paraphrohaemolyticus is not closely related to either $H$. aphrophilus or $H$. paraphrophilus.

\section{LITERATURE CITED}

1. Biberstein, E. L., and K. Zinnemann. 1982. International Committee on Systematic Bacteriology Subcommittee on the Taxonomy of Haemophilus: minutes of the meeting, 3 and 4 September 1978. Int. J. Syst. Bacteriol. 32:244-245.

2. Calhoon, D. A., W. R. Mayberry, and J. Slots. 1981 Cellular fatty acid and soluble protein composition of Actinobacillus actinomycetemcomitans and related organisms. J. Clin. Microbiol. 14:376-381.

3. Christiansen, C., F. T. Black, and E. A. Freundt. 1981 Hybridization experiments with deoxyribonucleic acid from Ureaplasma urealyticum serovars I and VIII. Int. J. Syst. Bacteriol. 31:259-262.

4. Crosa, J. H., D. J. Brenner, and S. Falkow. 1973. Use of a single-strand-specific nuclease for analysis of bacterial and plasmid deoxyribonucleic acid homo- and heteroduplexes. J. Bacteriol, 115:904-911.

5. DeLey, J., H. Cattoir, and A. Reynaerts. 1970. The quantitative measurement of DNA hybridization from renaturation rates. Eur. J. Biochem. 12:133-142.

6. Ellner, J. E., M. S. Rosenthal, P. I. Lerner, and M. C. McHenry. 1979. Infective endocarditis caused by slow growing, fastidious, Gram-negative bacteria. Medicine (Baltimore) 58:145-158.

7. Hill, L. R. 1966. An index to deoxyribonucleic acid base compositions of bacterial species. J. Gen. Microbiol 44:419-437.

8. Irving, J. T., M. G. Newman, S. S. Socransky, and J. D. Heeley. 1975. Histological changes in experimental periodontal disease in rats monoinfected with a Gram-negative organism. Arch. Oral Biol. 20:219-220.

9. Johnson, J. L. 1973. Use of nucleic acid homologies in the taxonomy of anaerobic bacteria. Int. J. Syst. Bacteriol 23:308-315.

10. Johnson, J. L., and E. J. Ordal. 1968. Deoxyribonucleic acid homology in bacterial taxonomy: effect of incubation temperature on reaction specificity. J. Bacteriol. 95:893900.

11. Johnson, J. L., C. F. Phelps, C. S. Cummins, J. London, and F. Gasser. 1980. Taxonomy of the Lactobacillus acidophilus group. Int. J. Syst. Bacteriol. 30:53-67.

12. Khairat, O. 1940 . Endocarditis due to a new species of Haemophilus. J. Pathol. Bacteriol. 50:497-505.
13. Kilian, M. 1976. A taxonomic study of the genus Haemo philus, with the proposal of a new species. J. Gen. Microbiol. 93:9-61

14. Kilian, M., J. Nicolet, and E. L. Biberstein. 1978. Biochemical and serological characterization of Haemophilus pleuropneumoniae (Matthews and Pattison 1961) Shope 1964 and proposal of a neotype strain. Int. J. Syst. Bacteriol. 28:20-26.

15. Kilian, M., W. Prachybrued, and E. Theilade. 1976 Haemophili in developing dental plaque. Scand. J. Dent. Res. 84:16-19.

16. Kilian, M., and C. R. Schiott. 1975. Haemophili and related bacteria in the human oral cavity. Arch. Oral Biol. 20:791-796.

17. King, E. O., and H. W. Tatum. 1962. Actinobacillus actinomycetemcomitans and Haemophilus aphrophilus J. Infect. Dis. 111:85-94

18. Kraut, M. S., H. R. Attebery, S. M. Finegold, and V. L. Sutter. 1972. Detection of Haemophilus aphrophilus in the human oral flora with a selective medium. J. Infect. Dis. 126:189-192.

19. Mandell, R. L., and S. S. Socransky. 1981. A selective medium for Actinobacillus actinomycetemcomitans and the incidence of the organism in juvenile periodontitis. $\mathbf{J}$. Periodontol. 52:593-598.

20. Mannheim, W., S. Pohl, and R. Hollander. 1980. Zur Systematik von Actinobacillus, Haemophilus, und Pas turella. Zentralbl. Bakteriol. Parasitenkd. Infektionskr. Hyg. Abt. 1 Orig. Reihe A 246:512-540.

21. Marmur, J. 1961. A procedure for the isolation of deoxyribonucleic acid from microorganisms. J. Mol. Biol. 3:208218.

22. Marmur, J., and P. Doty. 1961. Thermal renaturation of deoxyribonucleic acids. J. Mol. Biol. 3:585-594.

23. Marmur, J., and P. Doty. 1962. Determination of the base composition of deoxyribonucleic acid from its thermal denaturation temperature. J. Mol. Biol. 5:109-118.

24. Pohl, S. 1981. DNA relatedness among members of Haemophilus, Pasteurella, and Actinobacillus, p. 245-253. In M. Kilian, W. Frederiksen, and E. L. Biberstein (ed.), Haemophilus, Pasteurella and Actinobacillus. Academic Press, Inc., New York.

25. Potts, T. V., L. V. Holdeman, and J. Slots. 1983. Relationships among the oral fusobacteria assessed by DNA-DNA hybridization. J. Dent. Res. 62:702-705.

26. Slots, J. 1982. Salient biochemical characters of Actinobacillus actinomycetemcomitans. Arch. Microbiol. 131:6067.

27. Slots, J., H. S. Reynolds, and R. J. Genco. 1980. Actinobacillus actinomycetemcomitans in human periodontal disease: a cross-sectional microbiological investigation. Infect. Immun. 29:1013-1020.

28. Slots, J., J. J. Zambon, B. G. Rosling, H. S. Reynolds L. A. Christersson, and R. J. Genco. 1982. Actinobacillus actinomycetemcomitans in human periodontal disease association, serology, leukotoxicity, and treatment. J Periodontal Res. 17:447-448.

29. Sneath, P. H. A., and R. Johnson. 1973. Numerical taxonomy of Haemophilus and related bacteria. Int. J. Syst. Bacteriol. 23:405-418.

30. Sutter, V. L., and S. M. Finegold. 1970. Haemophilus aphrophilus infections: clinical and bacteriologic studies Ann. N.Y. Acad. Sci. 174:468-487.

31. Tanner, A. C. R., C. Haffer, G. T. Bratthall, R. A. Visconti, and S. S. Socransky, 1979. A study of the bacteria associated with advancing periodontitis in man. J. Clin. Periodontol. 6:278-307.

32. Zinnemann, K. 1980 . Newer knowledge in classification, taxonomy, and pathogenicity of species in the genus Haemophilus: a critical review. Zentral. Bakteriol. Parasitenkd. Infektionskr. Hyg. Abt. 1 Orig. Reihe A 247:248 258.

33. Zinnemann, K., K. B. Rogers, J. Frazier, and J. M. H. 
Boyce. 1968. A new V-dependent Haemophilus species preferring increased $\mathrm{CO}_{2}$ tension for growth and named Haemophilus paraphrophilus, nov. sp. J. Pathol. Bacteriol. 96:413-419.
34. Zinnemann, K., K. B. Rogers, J. Frazier, and S. K. Devaraj. 1971. A haemolytic V-dependent $\mathrm{CO}_{2}$-preferring Haemophilus species (Haemophilus paraphrohaemolyticus nov. spec.) J. Med. Microbiol. 4:139-143. 